\title{
Proces deregulacji elektroenergetyki w Polsce na tle przemian strukturalnych tego sektora w krajach Unii Europejskiej
}

Procesy transformacji ustroju w Polsce w kierunku gospodarki rynkowej, postępująca stopniowo integracja z Unią Europejską, a także włączenie naszego kraju w struktury zachodnioeuropejskiej elektroenergetyki (UCPTE, X.1995r.) wywieraja istotny wpływ na kierunki i dynamikę przekształceń strukturalnych zachodzących w latach 90-tych w krajowym sektorze elektroenergetyki.

Od przełomu lat 80-tych i 90-tych w krajach zachodnioeuropejskich wprowadzane są stopniowio nowe modele funkcjonowania elektroenergetyki, których ideą jest utworzenie wewnętrznego, w pełni konkurencyjnego rynku energii elektrycznej i uznanie jej jako towaru rynkowego (Liberalizacja... 1999). Wymaga to przeprowadzenia istotnych zmian w dotychczasowej organizacji elektroenergetyki określanych jako proces deregulacji. Proces ten ma wieloaspektowy i złożony charakter. Obejmuje on przede wszystkim: demonopolizację (dezintegrację pionową sektora), prawo wejścia na rynek nowych tzw. niezależnych wytwórców, swobodny wybór dostawcy przez odbiorców energii elektrycznej, równoprawne traktowanie przedsiębiorstw energetycznych ( bez względu na formę własnościowa), wyeliminowanie monopolistycznej roli państwa w ustalaniu cen i taryf na energię elektryczną (Jeżewski 1999, Liberalizacja...1999).Warunkiem koniecznym efektywnej konkurencji na rynku energii jest zróżnicowana forma własnościowa jego podmiotów, stąd konieczność przeprowadzenia przekształceń własnościowych sektora.

Głównym celem artykułu jest analiza i ocena procesu deregulacji polskiej elektroenergetyki w latach 90-tych, w kontekście przemian zachodzących w tym zakresie w krajach Unii Europejskiej. Przebieg tego procesu, osiągnięte rezultaty będą z pewnością warunkować pozycję elektroenergetyki Polski na kreowanym obecnie w Europie konkurencyjnym rynku energii elektrycznej. Identyfikacja, interpretacja oraz uporządkowanie czynników i przesłanek, które warunkują ten proces wydaje się być koniecznym uzupełnieniem niniejszego artykułu, niezbędnym dla zrozumienia postępujących, głębokich przekształceń strukturalnych elektroenergetyki.

\section{Czynniki i przesłanki zmian strukturalnych elektroenergetyki}

Współczesne przekształcenia strukturalne elektroenergetyki determinowane są przez czynniki i przesłanki o zróżnicowanej genezie i o odmiennym charakterze. Można je połączyć w trzy grupy. 
Pierwsza $\mathrm{z}$ nich wiąże się z zachodzącymi zmianami techniczno-technologicznymi w elektroenergetyce takimi jak:

- stopniowym wyczerpywaniem się w rozwiązaniach technicznych tzw. korzyści wielkiej skali z tytułu koncentracji mocy w coraz to większych turbozespołach,

- przełomem technologicznym w zakresie budowy i eksploatacji elektrowni gazowo-parowych, które w porównaniu z elektrowniami węglowymi cechują się niższymi nakładami i krótszym okresem inwestycyjnym, wyższą sprawnością przemian energetycznych, większą swobodą lokalizacyjną, oraz są bardziej przyjazne środowisku,

- rozwojem systemów sterujących i pomiarowo-rozliczeniowych warunkujących funkcjonowanie rozwiązań rynkowych w elektroenergetyce.

Druga grupa czynników i przesłanek wynika ze zmian w strukturze nośników energii i paliw użytkowanych w elektrowniach. Są to:

- dynamicznie wzrastający udział gazu ziemnego w produkcji energii elektrycznej kosztem paliw węglowych i energii jądrowej,

- rozwój wykorzystania rozproszonych w przestrzeni odnawialnych źródeł energii o wybitnie lokalnym zasięgu oddziaływania.

Trzecią grupę stanowią przesłanki o charakterze społeczno-ekonomicznym i politycznym. Tutaj należy zwrócić uwagę na:

- nadmierne zatrudnienie oraz niewystarczającą w stosunku do innych działów gospodarki innowacyjność w zbiurokratyzowanych i zetatyzowanych państwowych koncernach energetycznych,

- wiązanie poprawy ekonomicznej działania sektora z relokacją elektrowni i decentralizacją zarządzania,

- zwiększenie konkurencyjności gospodarki europejskiej przez obniżenie kosztów energii elektrycznej w wyrobie finalnym,

- zniesienie moratorium dla kapitału zagranicznego pragnącego inwestować w sektorze energetycznym,

- pojawienie się na przełomie lat 80-tych i 90-tych nowych możliwości współpracy krajów europejskich po zmianie sytuacji politycznej i upadku realnego socjalizmu.

Przedstawione powyżej czynniki i przesłanki stały się bodźcem do zainicjowania, a następnie kontynuacji $\mathrm{z}$ różną dynamiką procesu deregulacji elektroenrgetyki w krajach europejskich, w tym i w Polsce. Jego głównym celem jest zwiększenie efektywności funkcjonowania sektora, co przyniesie wymierne korzyści społeczno-ekonomiczne w postaci obniżenia cen energii elektrycznej dla użytkowników.

\section{Rozwój i zakres deregulacji elektroenergetyki w krajach Unii Europejskiej}

Funkcjonowanie elektroenergetyki w skali krajowej lub regionalnej odbywało się zazwyczaj w pionowo zorganizowanych podmiotach gospodarczych, które bez względu na formę własności korzystały niejednokrotnie z pomocy finansowej rządów, z uwagi na strategiczną rolę jaką pełniły - niezawodną dostawę energii elektrycznej. Źródłem korzyści dla sektora stał się również status użyteczności publicznej, który zapewniał firmom monopolistyczną pozycję na rynku, subsydiowanie energii, łatwy dostęp do kredytów inwestycyj- 
nych pochodzących ze środków publicznych. Zachowanie bezpieczeństwa dostawy energii sankcjonowało niejako kontrolę rządów nad sektorem energetycznym.

Powyższe charakterystyczne cechy rozwojowe wykazywała elektroenergetyka zarówno w krajach o gospodarce rynkowej jak również w krajach o nakazowo-rozdzielczym systemie gospodarki. Nowe wzorce funkcjonowania elektroenergetyki pojawiły się w Europie na przełomie lat 80-tych i 90-tych. Już w okresie1989-1993 rządy W. Brytanii, Finlandii, Norwegii i Szwecji wycofały się ze strategicznej roli stymulowania rozwoju elektroenergetyki oraz bezpośredniego zapewnienia bezpieczeństwa i suwerenności energetycznej kraju, a następnie rozpoczęły od połowy lat 90 -tych stopniową deregulację sektora.

Struktura organizacyjna sektora elektroenergetyki, jego stopień integracji pionowej (technologicznej) i poziomej (przestrzennej) jest zróżnicowany w krajach członkowskich Unii Europejskiej.W 1999r. zintegrowane pionowo, państwowe firmy elektroenergetyczne, o krajowym zasięgu przestrzennym, realizujące pełną usługę od wytwarzania po dostarczenie energii elektrycznej odbiorcy końcowemu występowały w Francji (Elektricite de France), Włoszech (Enel), Grecji (PPC) i Irlandii (ESB). Natomiast w Niemczech wyłącznością obsługi energetycznej na wydzielonym obszarze dysponuje 9 koncernów energetycznych (RWE, Preussen Elektra, EVS, Bewag, Bayernverk, HEW, Badenverk, VEW i VEAG) , będących własnością prywatną, lub mieszaną. Kraje te odgrywają decydującą rolę na wewnętrznym europejskim rynku, ze względu na potencjał energetyczny, który w Niemczech stanowi 23\% sumarycznej produkcji krajów członkowskich Unii, w Francji $19 \%$, w Włoszech $12 \%$.

W krajach Unii funkcjonują także pośrednie formy integracji pionowej obejmującej np. produkcję i przesyłanie (Belgia, Dania), przesyłanie i dystrybusję (Luksemburg), czy produkcję i dystrybucję (Hiszpania). W ostatnich latach zaobserwować można nasilenie się procesów konsolidacji w obrębie poszczególnych segmentów sektora elektoenergetyki w Wielkiej Brytanii, Hiszpanii Belgii, w celu zwiększenia konkurencyjności zintegrowanych firm na ogólnoeuropejskim rynku energii elektrycznej.

Najwcześniej procesy deregulacji elektroenergetyki rozpoczęły się w W. Brytanii. W 1989 r. rząd W. Brytanii przeprowadził demonopolizację państwowego sektora elektroenergetyki - Centralnego Zarządu Wytwarzania Energii Elektrycznej (CEGB), polegającą na rozdzieleniu poszczególnych faz procesu technologicznego między odrębne przedsiębiorstwa zajmujące się wytwarzaniem (koncerny National Power i Power Gen), przesyłaniem (National Grid Company) i dystrybucją energii elektrycznej (12 Regional Electricity Companies). Przekształceniom organizacyjnym towarzyszył proces prywatyzacji, który został zakończony w połowie lat 90-tych (Prywatyzacja...1996). Należy podkreślić, że wówczas W. Brytania była pionierem i wiodła prym wśród krajów Unii Europejskiej w zakresie przedsięwzięć reorganizacyjnych elektroenergetyki.

Warunkiem koniecznym funkcjonowania otwartego, konkurencyjnego rynku energii elektrycznej jest wprowadzenie zasady swobodnego korzystania z sieci przesyłowej zarówno dla odbiorców jak i dla niezależnych wytwórców energii - tzw. zasady Third Part Acces (TPA). Na początku lat 90-tych Komisja Europejska przedstawiła krajom członkowskim Unii projekt TPA o obligatoryjnym charakterze, który wywołał liczne dyskusje i kontrowersje. Dlatego też w jego miejsce w 1993 r. wprowadzono tzw. regulowaną i negocjowaną zasadę korzystania z sieci przesyłowych (Regulated and Negotiated TPA) oraz zachowano prawo wyłącznego nabywcy energii elektrycznej (Single Bayer). 
Na początku lat 90 -tych, zgodnie z projektem Regulated Third Part Acces rozpoczął funkcjonowanie rynek energii elektrycznej w W. Brytanii (Pool) i w krajach skandynawskich (tzw. Nordpool). Za prawidłowe kształtowanie kosztów produkcji i cen na energię elektryczną odpowiada w powyższych krajach rządowy organ - Agencja Regulacji Energetyki. Tak więc kraje te zainicjowały pionierski proces liberalizacji rynku energii elektrycznej wyprzedzając w tym zakresie decyzję Parlamentu Europejskiego.

Reguły konkurencji i sprawy unifikacji wewnętrznego rynku energii elektrycznej określa Dyrektywa nr 96/92/EC,opracowana przez Ministrów Energetyki i Parlament Europejski (Dyrektywa... 1997). W krajach członkowskich zaczęła ona obowiązywać od 1997r. Rozporządzenie to umożliwia indywidualne określenie grup odbiorców uprawnionych do udziału w rynku. W trybie natychmiastowym skorzystali $\mathrm{z}$ tego rozporządzenia odbiorcy o zużyciu energii elektrycznej powyżej $100 \mathrm{GWh}$ w skali roku. Dyrektywa obliguje kraje Unii do stopniowego otwierania rynku energii na konkurencję. Zgodnie z przyjętym harmonogramem stopień otwarcia rynku powinien wynieść: $25 \%$ w 1999 r., $28 \%$ w 2000 r., $33 \%$ w 2003 r. i $100 \%$ w 2006 r.

Niektóre kraje członkowskie Unii deklarują przyśpieszenie otwarcia rynku w stosunku do przyjętego w harmonogramie. Na przykład W. Brytania, Niemcy, Szwecja, Finlandia zobowiązały się do wprowadzenia pełnej konkurencji już w 2003r., a Hiszpania i Holandia w 2005r. Jeśli chodzi o zasady korzystania z sieci przesyłowej i dystrybucyjnej to wszystkie kraje Unii przyjęły regulowany dostęp, z wyjątkiem Niemiec, Grecji i Danii, gdzie obowiązuje negocjowana zasada.

Dyrektywa 96/92/EC zawiera również stanowisko Unii Europejskiej w sprawie lokalizacji nowych elektrowni. Zgodnie $\mathrm{z}$ nim od 1999r. każdy inwestor ma prawo zlokalizować elektrownię i generować energię elektryczną w dowolnie wybranym kraju Unii, uzyskawszy uprzednio koncesję na prowadzenie tej działalności lub poddając się procedurze wyboru ofert.

Reasumując, wprowadzona dyrektywa dokonała przełomu w deregulacji elektroenergetyki, uruchomiła nieodwracalny proces kreowania konkurencyjnego, otwartego rynku energii elektrycznej w Europie Zachodniej, przy czym jego dynamika i zakres merytoryczny kształtowany jest w znacznej mierze przez politykę energetyczną poszczególnych krajów. Konsekwencją deregulacji elektroenergetyki w W. Brytanii, Finlandii, Norwegii, Szwecji jest obniżenie cen na energię elektryczną w tych krajach przeciętnie o 15-20\% w porównaniu z połową lat 90-tych.

Dyrektywa umożliwia elastycznie podejście do metody realizacji jej założeń. Świadczą o tym następujące zalecenia odnośnie:

- stopniowego wprowadzania konkurencji, aby uczestnicy rynku mieli niezbędny czas na dostosowanie się do nowych zasad

- dowolności przy wyborze metod służących do osiągnięcia założonego celu, jakim jest $33 \%$ otwarcie rynku w 2003 r.

- pozostawienia zasady użyteczności publicznej sektora, interpretowanej jako zapewnienie ciągłości dostawy energii elektrycznej, przy zachowaniu wymogów ochrony środowiska.

Wprowadzanie wewnętrznego, konkurencyjnego rynku energii elektrycznej w krajach Unii Europejskiej, których sumaryczna podaż stanowi $72 \%$ energii elektrycznej wytwarzanej w Europie (bez Rosji), wpływa na kierunki kształtowania się struktur organizacyjnych elektroenergetyki w krajach europejskich funkcjonujących poza tym ugrupowaniem gospodarczym. 


\title{
Deregulacja i przeksztalcenia wlasnościowe polskiego sektora elektroenergetyki
}

\author{
Dezintegracja pionowa
}

Przemiany polityczne w 1989r. i wprowadzenie gospodarki rynkowej stały się impulsem do uruchomienia przekształceń strukturalnych w sektorze elektroenergetyki. Do 1990r. sektor ten tworzył państwowy monopol naturalny o zasięgu ogólnokrajowym, którego struktura organizacyjna była zintegrowana pionowo. Ustawa sejmowa z lutego 1990r. umożliwiła dekompozycję pionową elektroenergetyki, to jest organizacyjne rozdzielenie między odrębne przedsiębiorstwa poszczególnych faz procesu technologicznego obejmującego wytwarzanie, przesyłanie i dostawę energii elektrycznej do konsumenta. W miejsce monopolistycznego przedsiębiorstwa Wspólnota Energetyki i Węgla Brunatnego powołano samodzielnie finansowo i organizacyjnie podmioty gospodarcze zajmujące się wytwarzaniem (63 elektrownie cieplne zawodowe), przesyłaniem (Polskie Sieci Elektroenergetyczne S.A.) i dystrybucją energii elektrycznej (33 obszarowe zakłady energetyczne).

Powierzenie PSE S.A., pierwszej w sektorze elektroenergetycznym spółce akcyjnej Skarbu Państwa, funkcji operatora systemu przesyłowego i jedynego podmiotu zajmującego się hurtowym obrotem energią elektryczną oznaczało, że rząd w 1990r. wprowadził na rynku zasadę jednego kupca (single bayer). Ustawa z 1990 r. nie dotyczyła elektrowni przemysłowych ( 310 obiektów), których właścicielami pozostały zakłady przemysłowe. W ramach restrukturyzacji organizacyjnej przemysłu elektrownie te przekształca się stopniowo w spółki z ograniczoną odpowiedzialnością. Przeprowadzona w 1990r. demonopolizacja Wspólnoty Energetyki i Węgla Brunatnego nawiązywała do rozwiązań przyjętych w Wielkiej Brytanii, które traktowano wówczas jako modelowe. Wiąże się to niewątpliwie $\mathrm{z}$ faktem, że na początku lat 90-tych angielska firma konsultingowa Coopers and Lybrand była głównym doradcą PSE S.A.. Poza tym w zakresie przemian strukturalnych elektroenergetyki, W. Brytania jest niepodważalnym pionierem.

W stosunku do początku lat 90-tych złagodzeniu uległo stanowisko Unii Europejskiej co do obligatoryjności wprowadzenia zasady pionowej dezintegracji przedsiębiorstwa energetycznego. Obecnie nie ma potrzeby dokonywania tak radykalnych zmian organizacyjnych, wystarczy oddzielić operacje finansowo-księgowe dla poszczególnych faz procesu technologicznego obejmującego wytwarzanie, przesyłanie i dystrybucję energii elektrycznej (Dyrektywa... 1996).

Po 1993r. proces deregulacji polskiego sektora elektroenergetyki został praktycznie wstrzymany, aż do uchwalenia przez Sejm w kwietniu 1997r. prawa energetycznego. Określiło ono docelowy model strukturalny polskiej elektroenergetyki, oraz unormowało zasady funkcjonowania sektora. Wprowadzenie w życie tego ważnego dokumentu jest niewątpliwie zasługę ugrupowań solidarnościowych, które w tym czasie ponownie doszły do władzy wykonawczej.

Prawo energetyczne obliguje podmioty gospodarcze do uzyskania koncesji, na prowadzenie działalności związanej z produkcja przesyłaniem i dystrybucją energii elektrycznej, a także reguluje zasady korzystania z sieci przesyłowych tzw. stron trzecich. Rezygnacja z formuły użyteczności publicznej sektora otwiera drogę przedsiębiorstwom energetycznym do zróżnicowania działalności poza stricte energetyczną. W celu równoważenia interesów wytwórców i odbiorców energii elektrycznej oraz zapobieżeniu praktykom monopolistycznym utworzono Urząd Regulacji Energetyki. Ten niezależny od rządu, naczelny organ 
administracji sprawuje nadzór nad wprowadzaniem przepis $6 \mathrm{w}$ prawa energetycznego w życie, między innymi zatwierdza ceny energii elektrycznej i taryfy usług przesyłowych. Jest sprawą dyskusyjną, na ile URE jest w stanie wyegzekwować od zakładów dystrybucji i elektrowni rzetelne rozliczenie wydatków finansowych na ponoszoną działalność usługową i produkcyjną .

Polskie prawo energetyczne zaczęło obowiązywać od stycznia 1998r., w tym samym czasie co prawo niemieckie, i zaledwie w dwa lata później po zatwierdzeniu brytyjskiego prawa. W zasadniczych kwestiach - deregulacji sektora elektroenergetyki koresponduje ono z ustaleniami zawartymi w Dyrektywie 96/92/EC Parlamentu i Rady Unii Europejskiej. Wyjątek stanowi zasada korzystania z usług przesyłowych, która w Polsce dotyczy wyłącznie energii elektrycznej wytworzonej na obszarze kraju.

\section{Przekształcenia własnościowe}

Pierwsze zmiany własnościowe w elektroenergetyce przyniosła ustawa z lutego 1993r. o przekształceniach przedsiębiorstw szczególnie ważnych dla gospodarki. Na jej podstawie w 1993r. skomercjalizowano 19 elektrociepłowni zawodowych. Dalsze zmiany wstrzymano do czasu ogłoszenia prawa energetycznego oraz przyjęcia przez Komitet Ekonomiczny Rady Ministrów (lipiec 1998) dokumentu określającego program prywatyzacji elektroenergetyki. W 1998 r. prywatyzację zakończono zaledwie $w$ dwóch przedsiębiorstwach prowadzących skojarzoną produkcję energii elektrycznej i energii cieplnej. Są to: Elektrociepłownia Kraków, której inwestorem strategicznym i właścicielem 55\% akcji został państwowy koncern Electricite de France oraz Elektrociepłownia Będzin, przez wprowadzenie akcji do publicznego obrotu na giełdę kapitałową (sprzedano $15 \%$ akcji). Na początku 2000r. większościowy pakiet akcji Elektrociepłowni Warszawskich (55\%) kupiła szwedzka korporacja energetyczna Vatenfall AB. W tym też roku planowana jest prywatyzacja Elektrociepłowni Wrocław (przez giełdę papierów wartościowych), oraz elektrociepłowni; Wybrzeże, Zielona Góra , Białystok, Toruń, w których przeznaczono do sprzedaży około $20-45 \%$ akcji.

W porównaniu z elektrociepłowniami, proces komercjalizacji zawodowych elektrowni cieplnych został bardziej wydłużony w czasie. W 1994r, status jednoosobowych spółek Skarbu Państwa uzyskały tylko dwa przedsiębiorstwa: Zespół Elektrowni PątnówAdamów-Konin (PAK) i El. Opole, a w 1995r. El. Łagisza. Pozostałe elektrownie skomercjalizowano w 1996r., z wyjątkiem EL. Bełchatów, gdzie zgodę Rady Pracowniczej na rozpoczęcie przekształceń własnościowych uzyskano dopiero w 1999r. Status przedsiębiorstwa państwowego zachowała El. Turów będąca w trakcie rekonstrukcji mocy, która zostanie ukończona w 2005r. W 1999r. sprzedano polskiemu konsorcjum utworzonego przez Elektrim 20\% Zespołu Elektrowni PAK. Wnioski prywatyzacyjne złożyły w Ministerstwie Skarbu dalsze elektrownie: Rybnik, Połaniec, Skawina, stąd należy sądzić, że na najbliższym czasie proces przekształceń własnościowych ulegnie przyśpieszeniu. W 2000r. planowana jest prywatyzacja elektrowni Skawina, której właścicielem $80 \%$ akcji ma zostać amerykański inwestor oraz sprzedaż akcji na giełdzie el. Bełchatów. Sprawą kontrowersyjną pozostaje decyzja rządu zastrzegająca, z obawy przed monopolistycznymi praktykami fuzję bezpośrednią lub przez tego samego inwestora następującym elektrowniom: Bełchatów, Kozienice, Dolna Odra, Jaworzno III, Laziska, Zespół PAK (Program... 1998). Jest to 
sprzeczne z postępującymi procesami konsolidacji elektrowni w Unii Europejskiej, prowadzonymi w celu uzyskania większej siły przebicia w transakcjach rynkowych.

W ramach przekształceń organizacyjno-własnościowych utworzono w 1998r. pierwsze konsorcjum paliwowo-energetyczne; Zakład Górniczo-Energetyczny Sobieski Jaworzno III, w którym kontrolny pakiet udziałów (51\%) objęła elektrownia. Tak szeroko dyskutowana przez analityków koncepcja tworzenia kompleksów paliwowoenergetycznych doczekała się realizacji. Korzyści z takiego rozwiązania są obustronne; elektrownia zapewniła sobie regularne dostawy węgla z pobliskiego szybu Sobieski, wydzielonego $\mathrm{z}$ likwidowanej kopalni Jaworzno, a kopalnia zachowała około 3 tys. miejsc pracy.

Omówienie zmian własnościowych w energetyce wodnej ograniczę do elektrowni szczytowo-pompowych, które w 1994r. skomercjalizowano, a następnie utworzono $\mathrm{z}$ nich spółkę Elektrownie Szczytowo-Pompowe S.A., w której $75 \%$ akcji objęły PSE S.A. Decyzja ta jest konsekwencją funkcji regulacyjno-interwencyjnej jaką pełnią te elektrownie, aby utrzymać parametry jakościowe energii elektrycznej w sieciach przesyłowych.

Komercjalizację 33 zakładów dystrybucji w 1993r. poprzedziła decyzja ówczesnego Ministerstwa Przemysłu i Handlu, o transferze do PSE S.A sieci przesyłowych wysokich napięc $(400 \mathrm{kV}, 220 \mathrm{kV}, 110 \mathrm{kV})$. Wywołała ona ostry sprzeciw dotychczasowych właścicieli tych sieci - zakładów energetycznych.

Sposób prywatyzacji sektora dystrybucji jest sprawa otwartą, nie wszystkie przedsiębiorstwa poszukują inwestora strategicznego. Narodowy charakter powinny zachować zakłady o dobrej kondycji finansowej. W 1999r. proces prywatyzacji najbardziej zaawansowany był w: Górnośląskim ZE S.A., Stołecznym ZE S.A., Energetyce Kaliskiej S.A. i ZE Toruń S.A..

W 1998r. przedsiębiorstwa dystrybucji na podstawie umów cywilno-prawnych utworzyły pięć grup konsorcyjnych: Północne, Zachodnie, Południowe, Południwo-Zachodnie, Południowo-Wschodnie. Poza tymi strukturami pozostał Stołeczny ZE S.A. Głównym celem powyższych fuzji jest zwiększenie zdolności kredytowych oraz uzyskanie większej wiarygodności w negocjacjach z elektrowniami podczas uzgadniania kontraktów na dostawy energii elektrycznej. To właśnie wygaśnięcie w 1998 r. średnioterminowych kontraktów asygnowanych przez PSE S.A. przyśspieszyło procesy konsolidacji w segmencie dystrybucji. Należy zaznaczyć, że zakłady dystrybucji mają dotąd dominującą pozycję na lokalnych rynkach energii, z której niejednokrotnie korzystają przy projektowaniu cen i taryf przesyłowych na energię elektryczną.

Do końca 1999r. monopolistyczną pozycję w segmencie przesyłowym w zakresie sieci wysokich napięć zachowały PSE S.A.. Firma ta realizuje także większość międzynarodowej wymiany energii elektrycznej, poza lokalnym, przygranicznym obrotem, w którym uczestniczą zakłady dystrybucji. W strukturach organizacyjnych PSE S.A. jest Krajowa Dyspozycja Mocy, która spełnia funkcje operatywne, polegające na bieżącym bilansowaniu popytu i podaży na energię elektryczną.

Efekty prywatyzacji polskiego sektora elektroenergetyki w latach 1993-1999 należy ocenić jako skromne, ze względu na długotrwałe dyskusje nad prawem energetycznym, jak również braku konsensusu odnośnie zakresu przedmiotowego i warunków programu pry watyzacji oraz politycznej woli przyśpieszenia przekształceń własnościowych. Generalnie zatrzymały się one na etapie komercjalizacji przedsiębiorstw, ale od 2000r. rząd przewiduje 
ich dynamizację. Produkcja energii elektrycznej ze sprywatyzowanych elektrowni stanowi obecnie około $16 \%$ krajowej podaży.

Zgodnie $\mathrm{z}$ programem rządowym przekształcenia własnościowe $\mathrm{w}$ elektroenergetyce mają zostać ukończone w 2003r. Usunięte zostały główne bariery spowalniające ten proces, jakimi były brak prawa energetycznego i programu prywatyzacji. Dalsze zmiany pójdą w kierunku zróźnicowania struktury własnościowej elektroenergetyki, przywrócenia własności komunalnej, powszechnie występującej w krajach Unii, właściwego wyważenia udziału kapitału zagranicznego, będącego stymulatorem innowacji organizacyjnotechnologicznych w elektorenergetyce. Według planów Ministerstwa Skarbu prywatni inwestorzy będą mogli przejąć około $30 \%$ udziałów w przedsiębiorstwach energetycznych. Przedsięwzięcia te $\mathrm{w}$ istotny sposób warunkują budowę konkurencyjnego rynku energii elektrycznej w Polsce. Warto podkreślić, że krajowa produkcja energii elektrycznej stanowi około 6,5\% sumarycznej podaży krajów Unii Europejskiej, a więc jest to rynek znaczący, o który warto zabiegać.

\section{Zachowanie rynkowe polskiej elektroenergetyki i ich efekty ekonomiczne, ekologiczne i przestrzenne}

Procesy deregulacji i bliska perspektywa uruchomienia w Polsce konkurencyjnego rynku energii elektrycznej, na którym ceny kształtowane będą przez popyt i podaż zainicjowała marketingowe zachowania w elektroenergetyce. Zaliczyć do nich należy szeroki program iwestycji modernizacyjnych i ekologicznych jakie podjęły krajowe elektrownie już na początku lat 90-tych. Jego celem jest sprostanie europejskim standardom w zakresie sprawności przemian energetycznych i poziomu emisji zanieczyszczeń. Ten bardzo kapitałochłonny program unowocześnienia i rekonstrukcji mocy wytwórczych został podjęty i jest kontynuowany dzięki kredytom bankowym na sumę około $4 \mathrm{mld}$ zł uzyskanym przez elektrownie. Wiarygodność spłaty zaciągniętych pożyczek jest zagwarantowana przez długoterminowe kontrakty na dostawy energii elektrycznej, jakie zawarło 17 elektrowni z PSE S.A. W 1994r. zaplanowano objęcie tą formą pomocy finansowej około $30 \%$ krajowego zapotrzebowania na energię, w 1999r. stanowiło to już 70\%. Dzięki kontraktom długoterminowym zmodernizowano około $3000 \mathrm{MW}$ mocy w elektrowniach (Popczyk 1998). Wymiernym efektem tych przedsięwzięć jest wyraźna poprawa w latach 90-tych wskaźników efektywności funkcjonowania elektrowni oraz obniżenie jednostkowej emisji zanieczyszczeń na wyprodukowaną $\mathrm{kWh}$ energii elektrycznej (tab.1,2). Ich wartości osiągnęły poziom porównywalny z przeciętnymi wskaźnikami elektroenergetyki bazującej na paliwach stałych w krajach Unii Europejskiej.

Kontrakty długoterminowe zawarte przez. PSE S.A. z elektrowniami, jako gwarancja spłaty zaciągniętych pożyczek wpłyną na kształtowanie się wzrostu krajowych cen energii elektrycznej w najbliższej dekadzie, w znacznym stopniu ograniczą także możliwości jej zakupu u tańszych producentów.

W wyniku procesu deregulacji na krajowym rynku energii elektrycznej pojawiły się nowe przedsiębiorstwa (tzw. niezależni producenci) prowadzące budowę i eksploatację elektrowni, nie związane $\mathrm{z}$ dotychczasowymi tradycyjnymi przedsiębiorstwami energetycznymi. Na podstawie dhugoterminowych kontraktów podpisanych z PSE S.A. mają one 
zagwarantowaną sprzedaż energii elektrycznej. Niezależni producenci, zgodnie z europejskimi trendami preferują budowę średniej wielkości elektrociepłowni gazowo-parowych bazujących na przewodowym gazie ziemnym.

Tab.l. Wybrane wskaźniki techniczno-ekonomiczne elektrowni cieplnych zawodowych w latach 90-tych

\begin{tabular}{|l||c|c|c|c||}
\hline \multicolumn{1}{|c|}{ Wyszczególnienie } & Jedn. & 1990 & 1995 & 1997 \\
\hline $\begin{array}{l}\text { Wskaźnik zużycia węgla kamiennego na produk- } \\
\text { cję energii elektrycznej }\end{array}$ & & & & \\
Energia paliwa & KJ/kWh & 9640 & 9050 & 8853 \\
Węgiel w jednostkach naturalnych & $\mathrm{G} / \mathrm{kWh}$ & 500 & 426 & 480 \\
\hline $\begin{array}{l}\text { Wskażnik zużycia węgla brunatnego na produkcję } \\
\text { energii elektrycznej }\end{array}$ & & & & \\
Energia paliwa & $\mathrm{KJ} / \mathrm{kWh}$ & 10500 & 10267 & 10278 \\
Węgiel w jednostkach naturalnych & $\mathrm{G} / \mathrm{kWh}$ & 1300 & 1209 & 1209 \\
\hline Ogólem & $\mathrm{KJ} / \mathrm{kWh}$ & 10000 & 9600 & 9504 \\
\hline Sprawnoś́ wytwarzania energii elektrycznej & $\%$ & 32,3 & 34,9 & 35,1 \\
Zatrudnienie na 1 MW mocy elektrycznej & os./MW & 1,16 & 1,03 & 0,97 \\
\hline
\end{tabular}

Źródło: Zestawiono na podstawie Statystyki Elektroenergetyki Polskiej 1998, ARE S.A.

Tab.2. Efekty ekologiczne modernizacji elektrowni cieplnych zawodowych w latach 90-tych na tle charakterystyki jakościowej paliwa

\begin{tabular}{|c|c|c|}
\hline \multirow{2}{*}{ Rodzaj zanieczyszczeń } & \multicolumn{2}{|c|}{ Emisja w kg/MWh } \\
\cline { 2 - 3 } & 1991 & 1998 \\
\hline Pyly & 4,9 & 0,9 \\
$\mathrm{SO}_{2}$ & 15,3 & 10,3 \\
$\mathrm{NO}_{x}$ & 4,1 & 2,7 \\
$\mathrm{CO}_{2}$ & 1556 & 1492 \\
\hline
\end{tabular}

Źródło: Biuletyn Miesięczny 7/99, PSE S.A.

Dokonano więc pierwszego, istotnego kroku w kierunku dywersyfikacji sektora wytwórczego, zdominowanego dotąd przez lobby paliw stałych. Wysokie walory środowiskowe elektrowni gazowych, niewielka powierzchnia pod zabudowę umożliwia ich lokalizację w bezpośrednim sąsiedztwie odbiorców energii. W 1999r. oddano do uzytku dwie takie elektrownie; pierwsza z nich stanowi własność amerykańskiego koncernu Enron (Nowa Sarzyna), druga należy do spółki akcyjnej o kapitale mieszanym Polish Energy Partners (Wizów k/Bolesławca). Inwestorami sześciu, będacych w trakcie budowy elektrowni gazowych są przedsiębiorstwa dystrybucji energii elektrycznej, znacznie oddalone od dużych producentów energii (tab.3). W sytuacji, gdy PSE S.A. skupiają około $70 \%$ hurtowego obrotu energią elektryczną, inwestowanie we własne źródła energii jest przejawem rynkowego podejścia przedsiębiorstw energetycznych. Należy podkreślić, że w funkcji odległości wzrastają koszty przesyłanej energii elektrycznej. 
Tab.3. Elektrownie gazowo-parowe oddane do użytku lub będące w budowie w latach 1997-1999

\begin{tabular}{|l|l|l|l|l|}
\hline Nazwa elektrowni & \multicolumn{1}{|c|}{$\begin{array}{c}\text { Moc } \\
\text { MWe }\end{array}$} & \multicolumn{2}{|c|}{$\begin{array}{c}\text { Data rozpoczęcia } \\
\text { budowy/eksploatacji }\end{array}$} & \multicolumn{1}{|c|}{ Inwestor } \\
\hline EC. Gorzów & 50 & 1997 & 1999 & EC Gorzów S.A. \\
EC. Nowa Sarzyna & 116 & 1998 & 1999 & Enron International \\
EC. Wizów & 21 & 1998 & 1999 & Polish Energy Partners S.A. \\
EC. Biała Podlaska & 50 & 1998 & & Lubelski ZE, Gmina M. Biała Podlaska \\
EC. Jarosław & 120 & 1998 & & Eastern Generation (49\%) Zamojski ZE \\
EC.Lublin Wrotków & 235 & 1998 & & Lubelski ZE \\
EC. Nietków & 50 & 1998 & & Ziclonogórski ZE, Ziel. Zakł. Nafty i Gazu \\
EC. Zamość & 130 & 1998 & & Zamojski ZE \\
\hline
\end{tabular}

Źródło: Opracowano na podstawie informacji PSE S.A.

Prawo energetyczne umożliwia zakupienie energii elektrycznej bezpośrednio u producenta, tak więc teoretycznie zakończony został monopol PSE S.A. na obrót energią. Pionierską decyzję w tym zakresie podjął w 1998r. Górnośląski ZE, podpisując z El. Rybnik bezpośrednią umowę na dostawy energii elektrycznej. Jest to pierwszy duży kontrakt podpisany i realizowany na rynku lokalnym, wyłamujący się z modelu single bayer. W 1999r. na rynku pojawiły się też pierwsze dwie firmy brokerskie zajmujące się dostawą energii elektrycznej przez sieci przedsiębiorstw dystrybucyjnych.

Konsekwencją postępującego procesu deregulacji sektora elektroenergetyki jest rozwój w latach 90-tych przedsiębiorczości lokalnej w zakresie wykorzystania odnawialnych źródeł energii (ryc.1). Małe elektrownie, wykorzystujące energię spadku wody, wiatru i biogaz generują energię elektryczną o niskich kosztach, zazwyczaj na obszarach wiejskich, gdzie dostępność do energii jest często ograniczona złym stanem technicznym sieci niskich napięć. Funkcjonowanie tych elektrowni, obok poprawy stanu środowiska, przynosi wielorakie korzyści społeczno-gospodarcze takie jak: kreowanie lokalnych rynków pracy, pobudzanie procesów inwestycyjnych w firmach dostarczających wyposażenie techniczne. Należy podkreślić, że wykorzystanie odnawialnych źródeł energii na terenach wiejskich wpływa także na lepsze zaspokojenie potrzeb energetycznych lokalnych społeczności, a tym samym podnosi poziom życia i umożliwia prowadzenie produkcji rolno-spożywczej. Napływ nowoczesnej technologii na tereny wiejskie, niejednokrotnie dotknięte deprywacją ekonomiczną, podniesienie ich bezpieczeństwa energetycznego powinno również sprzyjać rozwojowi lokalnych funkcji usługowo-produkcyjnych. 


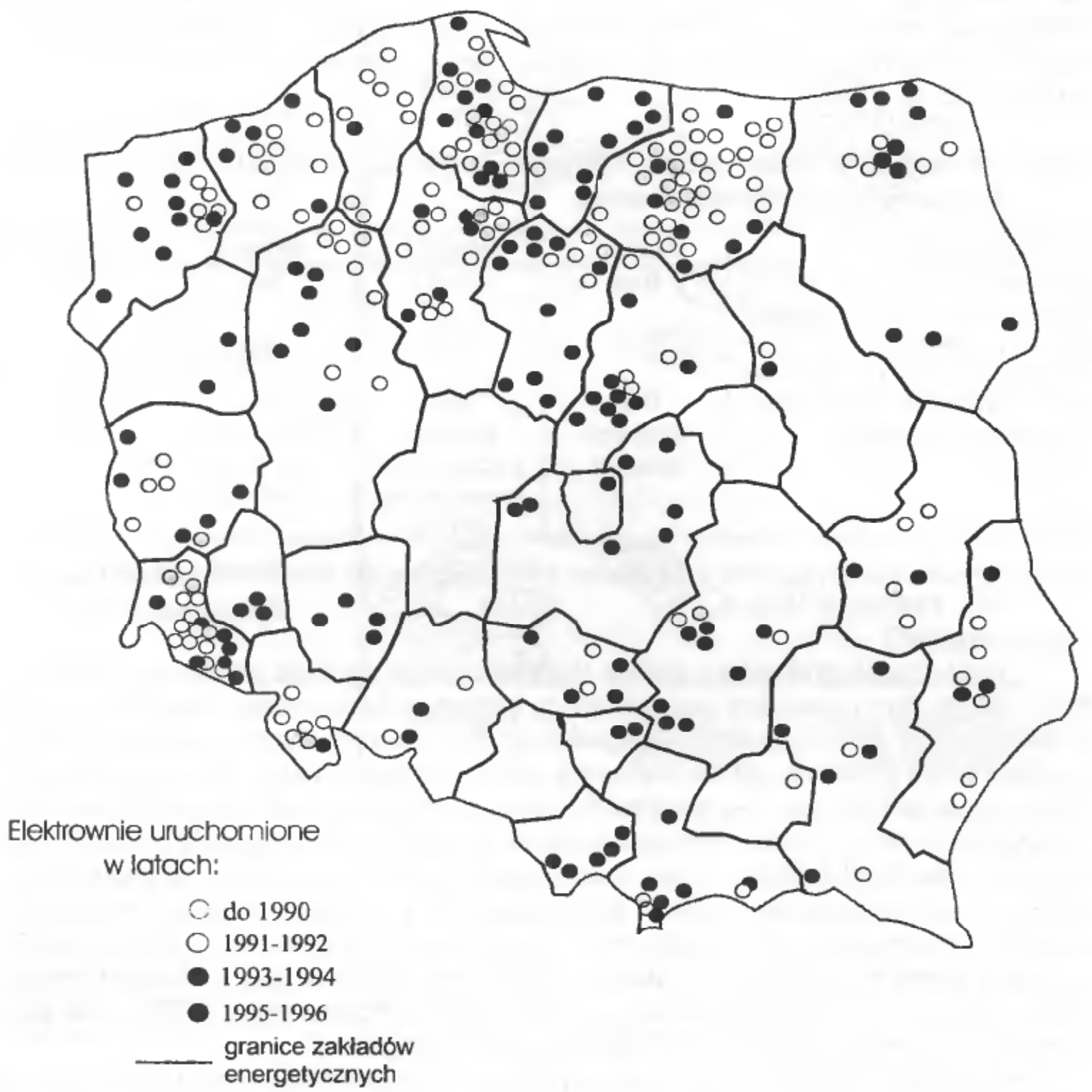

Ryc.1. Rozmieszczenie małych elektrowni sieciowych w Polsce w 1996r.

Źródło: Opracowanie własne na podstawie Statystyki Elektroenergetyki Polskiej 1997, ARE S.A.

\section{Stan deregulacji polskiego sektora elektroenergetyki na tle krajów Unii Europejskiej}

Istniejące i możliwe struktury organizacyjne elektroenergetyki można przedstawić za pomocą czterech modeli, które stanowią kolejne etapy przejścia od zintegrowanego pionowo do zderegulowanego, konkurencyjnego sektora elektroenergetyki (Ferretti 1997). $\mathrm{O}$ charakterze danego modelu decyduje występowanie lub brak takich faz rozwoju sektora 
jak: konkurencja w wytwarzaniu energii elektrycznej, możliwość wyboru dostawcy energii elektrycznej przez jej dystrybutora, możliwość bezpośredniego kupowania energii elektrycznej u dostawcy, porozumienia handlowe między uczestnikami rynku energii elektrycznej (tab.4).

Tab.4. Modele strukturalne sektora elektroenergetyki od zintegrowanego pionowo do konkurencyjnego-zderegulowanego

\begin{tabular}{|l|c|c|c|c|}
\hline Wyszczególnienie & Model 1 & Model 2 & Model 3 & Model 4 \\
\hline $\begin{array}{l}\text { Konkurencja w wytwarzaniu } \\
\text { Możliwość wyboru dostawcy } \\
\text { przez dystrybutora }\end{array}$ & Brak & Jest & Jest & Jest \\
$\begin{array}{l}\text { Możliwość wyboru dostawcy } \\
\text { przez użytkownika końcowego } \\
\text { Porozumienia handlowe }\end{array}$ & $\begin{array}{c}\text { Brak } \\
\text { Integracja } \\
\text { pionowa }\end{array}$ & $\begin{array}{c}\text { Brak } \\
\text { Kontrakty } \\
\text { zprzedsiębior- } \\
\text { stwami przesy- } \\
\text { lowymi }\end{array}$ & $\begin{array}{c}\text { Brak } \\
\text { Pool i kon- } \\
\text { trakty bezpo- } \\
\text { średnie }\end{array}$ & Post \\
\hline
\end{tabular}

Źródło: Opracowano na podstawie F. D. Ferretti, 1997, Financing the power sector in Eastern Europe. Proc. CEEPIF 97, Warsaw

Transformacja strukturalna sektora elektroenergetyki nie musi przebiegać stopniowo, przez kolejne fazy rozwojowe, prowadzące do konkurencyjnego rynku. Proces deregulacji, w zależności od sytuacji społeczno-gospodarczej kraju, woli politycznej aprobaty reform, wreszcie kondycji techniczno-ekonomicznej elektroenergetyki można przeprowadzić skokowo, łącząc niektóre fazy. Na przykład W. Brytania przeprowadziła zasadnicze przemiany strukturalne w dwóch fazach: pierwsza polegała na bezpośrednim przejściu z modelu 1 do modelu 3 (lata 1989-1992), a druga, zrealizowana w czery lata później na przejściu do modelu 4 (tab.4). Natomiast krajowa elektronergetyka, po przeprowadzonej dezintegracji pionowej, komercjalizacji przedsiębiorstw i wprowadzeniu w życie prawa energetycznego wykazuje pewne cechy modelu 3 takie jak: pojawienie się niewielkiej konkurencji, możliwość wyboru dostawcy przez zakłady energetyczne i częściowo przez użytkownika końcowego, utworzenie w grudniu 1999r. giełdy energii elektrycznej.

W układzie współrzędnych deregulacja - stosunki własnościowe możemy porównać miejsce polskiego sektora w relacji do krajów członkowskich Unii oraz krajów z nią stowarzyszonych, które podjęły i kontynuują proces deregulacji elektroenergetyki (ryc.2). Pod koniec lat 90-tych stopień zaawansowania przemian strukturalnych elektroenergetyki Polski należałoby określić jako początkowy, jednakże w najbliższych latach sektor ten będzie ewoluował zgodnie z trendami występującymi w Europie. Przy uwzględnieniu polskich uwarunkowań społeczno-ekonomicznych, poziomu zamożności gospodarstw domowych, dąży on do realizacji takich samych celów jakimi są pełna konkurencyjność w wytwarzaniu i dostawie energii elektrycznej oraz dywersyfikacja struktury własnościowej. 


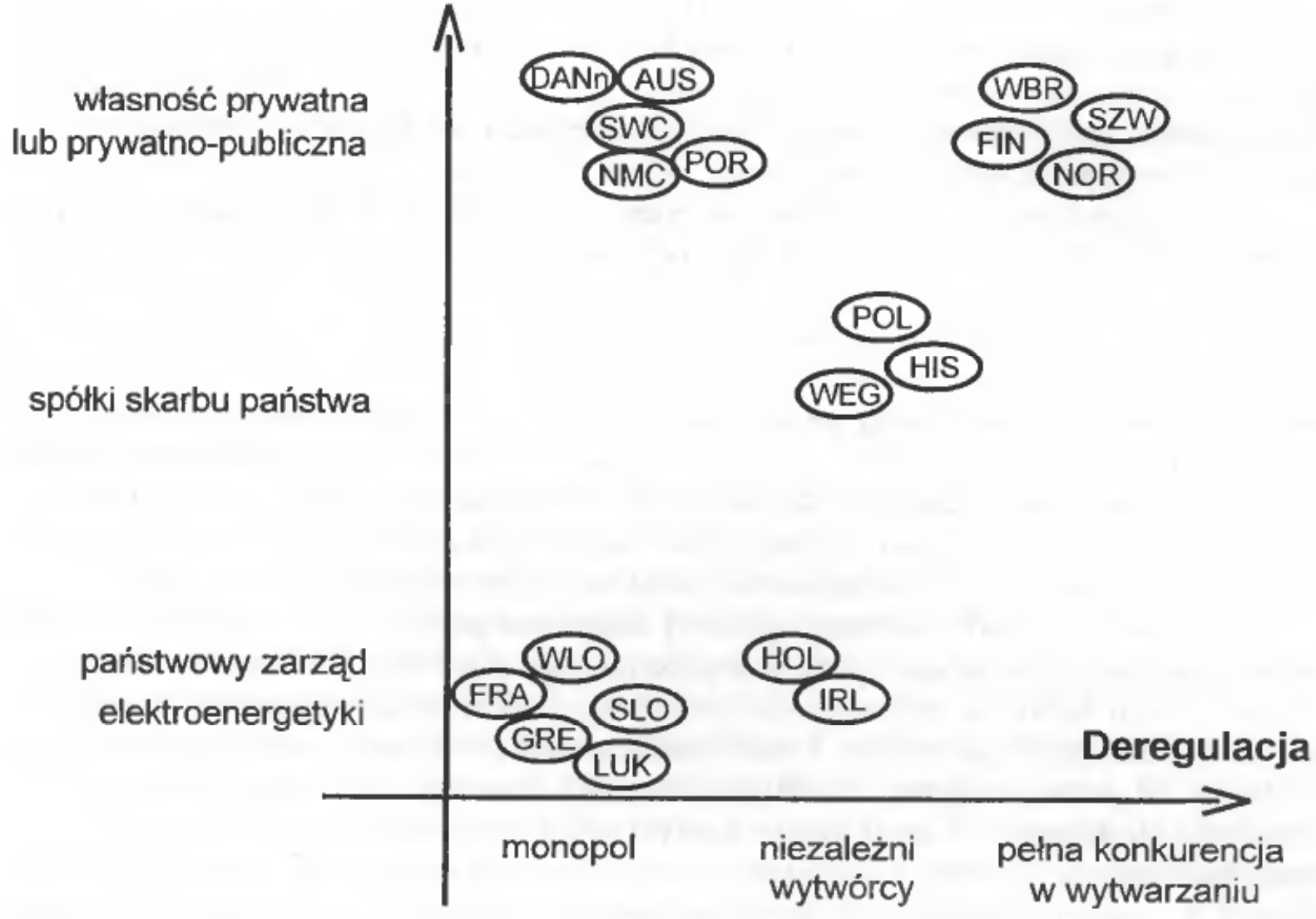

Objaśnienia skrótów:

$\begin{array}{ll}\text { FRA - Francja } & \text { IRL - Irlandia } \\ \text { GRE - Grecja } & \text { HOL - Holandia } \\ \text { WLO - Włochy } & \text { WEG - Węgry } \\ \text { SLO - Słowacja } & \text { POL - Polska } \\ \text { LUK - Luksemburg } & \text { HIS - Hiszpania } \\ \text { HOL - Holandia } & \text { DAN - Dania }\end{array}$

$$
\begin{aligned}
& \text { NMC - Niemcy } \\
& \text { POR - Portugalia } \\
& \text { AUS - Austria } \\
& \text { WBR - W. Brytania } \\
& \text { FIN - Finlandia } \\
& \text { SZW - Szwecja } \\
& \text { NOR - Norwegia }
\end{aligned}
$$

Ryc.2. Porównanie struktury organizacyjnej elektroenergetyki wybranych krajów ( $\operatorname{stan}$ z 1998r.)

Źródło: Opracowano na podstawie Biuletynów Miesięcznych PSE S.A.

O konkurencyjności rynku energii elektrycznej świadczy także zakres przedmiotowy zasady korzystania z sieci przesyłowych i dystrybucyjnych. W Polsce korzystanie z usług przesyłowych (zasada TPA) ma charakter ograniczony ponieważ dotyczy wyłącznie energii wytworzonej w kraju oraz warunkowy, gdyż istnieją przepisy, które mogą być podstawą do odmowy ich wykonania. (Prawo energetyczne, art.42). Zasada TPA jest zbliżona do mechanizmów wprowadzonych w krajach Unii, ale jest ostrożniejsza w otwieraniu rynku energii elektrycznej na międzynarodową konkurencję. Zagraniczni inwestorzy mogą korzy- 
stać z sieci przesyłowych jedynie w zakresie energii elektrycznej wytworzonej w Polsce. Jest to istotna rozbieżność $\mathrm{w}$ porównaniu $\mathrm{z}$ rozwiązaniami przyjętymi $\mathrm{w}$ Dyrektywie 96/92/EC, która z pewnością będzie musiała być wyeliminowana w ramach dostosowania polskiego prawa do obowiązującego w krajach Unii Europejskiej. Powstała ona w następstwie ochrony polskiego rynku energii elektrycznej przed nadmiernym importem tańszej energii $\mathrm{z}$ krajów Europy Zachodniej.

$\mathrm{Z}$ bezpośredniego prawa kupowania energii elektrycznej u producenta skorzystali w 1999r. tzw. odbiorcy zbiorowi (83 kategorie, w tym 33 zakłady energetyczne), którzy w skali roku dokonali sumarycznych zakupów energii elektrycznej powyżej $100 \mathrm{GWh}$. Lącznie dało to 36 \% stopień otwarcia rynku. W 2000r. odsetek ten zwiększy się do 43, dzięki obniżeniu poziomu rocznego zakupu energii do $40 \mathrm{GWh}$. W 2005 roku prawo do swobodnego korzystania $\mathrm{z}$ usług przesyłowych obejmie wszystkich odbiorców deklarujących taka potrzebę (Zerka 1998). Dla porównania, w 1999r. otwarty rynek energii elektrycznej dla wszystkich kategorii użytkowników funkcjonował w W. Brytanii, Finlandii, Norwegii, Szwecji. Jak wykazała praktyka tych krajów istotną barierą w wyborze dostawców energii przez odbiorców komunalnych są wysokie koszty indywidualnego opomiarowania.

Proces przemian strukturalnych polskiej elektroenergetyki przebiega zgodnie $\mathrm{z}$ trendami występującymi w krajach Unii Europejskiej. Jego dynamika jest kształtowana przez krajowe uwarunkowania społeczno-ekonomiczne, a także przez sekwencje ugrupowań politycznych będących w rządzie. Ewolucji sektora elektroenrgetyki rozumianej jako prze chodzenie od jednej struktury do drugiej, bardziej złożonej, towarzyszą głębokie przekształcenia strukturalne. Konsekwentna kontynuacja procesu deregulacji polskiej elektroenergetyki wpłynie zarówno na efektywność ekonomiczną sektora jak również przyniesie wielorakie pozytywne zmiany w jego strukturze przestrzennej. W najbliźszym okresie nasilą się takie korzystnych zmiany, które pojawiły się w początkowej fazie procesu deregulacji jak:

- zróżnicowanie struktury paliwowej elektroenergetyki, które spowoduje ograniczenie jej presji na środowisko oraz zwiększy stabilność i bezpieczeństwo energetyczne kraju,

- zróżnicowanie struktury własnościowej w trzech segmentach sektora (wytwarzania, przesyłania i dystrybucji energii elektrycznej), co powinno wpłynąć na dalszą dywersyfikację cen energii elektrycznej w przestrzeni,

- wystąpienie przestrzennej dyspersji elektroenergetyki jako konsekwencja orientacji elektrowni gazowych na rynek zbytu,

- dalsza poprawa wskaźników techniczno-ekomomicznych elektrowni w następstwie prowadzonej szerokiej modernizacji i rekonstrukcji urządzeń produkcyjnych.

Wydaje się, że najbardziej znamienne dla procesu deregulacji elektroenergetyki w Polsce będą implikacje przestrzenne, polegające na złagodzeniu istniejących skrajnych dysproporcji w zakresie produkcji i zużycia energii w przestrzeni, dzięki relokacji elektrowni. 


\section{Literatura}

Bojarski W., 1997, Problemy transformacji krajowej gospodarki energetycznej, Archiwum Energetyki, nr 1-2.

Dyrektywa 96/92/EC Parlamentu Europejskiego i Rady Unii Europejskiej z 19.12.1996 r.: W sprawie wspólnych zasad wewnętrznego rynku energii elektrycznej, Fakty i Dokumenty PSE S.A., nr 1, 1997.

Electricity Suplay Industry, Structure, Ownership and Regulation in OECD Countries, 1994, OECD/IEA.

Ferretti F.D., 1997, Financing the power sector in Eastern Europe, proc. CEEPIF 97, Warsaw,

Jeżowski P., 1999, Restrukturyzacja krajowych monopoli naturalnych w Polsce, Gospodarka Narodowa, nr 4, s.30-40.

Liberalizacja i prywatyzacja sektora energetyki. Raport Międzynarodowej lzby Handlowej Unii Europejskiej, 1999, Biuletyn Miesięczny nr 9.

Luchter L., 2000, Rozwój i uwarunkowania przedsiębiorczości w zakresie wykorzystania odnawialnych źródel energii w Polsce, Prace Geograficzne IG UJ, nr 106.

Malko J., Zerka M., 1997, Kapital zagraniczny w energetyce polskiej - strategia inwestowania, Elektroenergetyka, nr 3, PSE S.A., s 7-11.

Nowe niemieckie prawo energetyczne, 1998, Fakty i Dokumenty, nr 3, PSE S.A.

Popczyk J. 1998, Elektroenergetyka w polowie 1998r., Energetyka, nr 9.

Prawo energetyczne, Ustawa z 10.04.1997, Dziennik Ustaw 1997, nr 54, poz.348.

Program oraz uwarunkowania prywatyzacji sektora energetycznego. Materiał przyjęty przez Komitet Ekonomiczny Rady Ministrów w dniu 30.07.1998,

Prjwatyzacja elektroenergetyki w Anglii $i$ Walii,1996, Fakty i Dokumenty, nr 1,

PSE S.A.

Szablewski A., 1992, Teoretyczne przestanki deregulacji infrastruktury, Ekonomista nr 3.

Zerka M., 1998, Dostep stron trzecich do sieci przesylowych i rozdzielczych, Biuletyn Miesięczny nr 8, PSE S.A. s.21 - 25. 